\title{
Psychological analysis of the problem of post-truth in Bulgaria
}

\begin{abstract}
The subject of this article is the dichotomy between reality and falsehood (information vs. disinformation) in the media environment of Bulgaria and its effects on society, public governance and crowd psychology as a whole. Where is the truth behind the loud titles? How did we reach the age of the so called "post-truth"? Why are modern media and social networks abounding in misleading messages that spread like a virus in society? We will also try to answer the question: why did the public image of the European Union suddenly become so unattractive in some East and Central European countries? And another key issue - why is the 'nationalist trend' in the political psychology so profitable in Bulgaria as well as in other East-European countries?
\end{abstract}

Volume 9 Issue 2 - 2018

\author{
Desislava Damyanova \\ Department of Philosophy, Sofia University, Bulgaria
}

Correspondence: Desislava Damyanova, Department of Philosophy, Sofia University, Bulgaria, Email dessislavadd@yahoo.com

Received: December 14, 2017 | Published: April 10, 2018

\section{Introduction}

The so called "post-truth" is a global phenomenon due to technology, economic expansion and the spread of populist propaganda and disregard for "objective facts". In the political psychology these facts are considered to be "less influential in shaping public opinion than appeals to emotion and personal belief". ${ }^{2}$ In a narrow sense posttruth depicts the facts misrepresented by mass communication - a new media reality beyond any objectivity. Over the last few years we have been living in what is called an "information bubble" - a circle of likeminded people who share common visions and hopes for the future. Their worldview, however, is often radically different from that of other 'bubbles', of people with different beliefs and understandings. "It is not only the case that psychology - at least its social, cultural, cognitive and political branches - deals with public opinion and the emergence and transformation of (social) knowledge. What matters most is that psychology cannot stop at simply discovering new biases and errors in thinking processes, new dynamics within inter-group relations, or listing new forms of manipulation." ${ }^{3}$ We need a new analytical research that will explore the facts - people already live in different 'mythologies', express themselves in different languages and do not touch the information bubbles of others. Sometimes it seems that the distance between the languages of communication has increased so much that we have fallen into a clan or group isolationism. Various coping strategies are being compiled to interpret the world, the local history and the fate of next generations in Bulgaria - all of them with dubious authenticity. "What is at stake in defining a new role for psychology within the post-truth era is not only the future of the discipline, faced with the double challenge of anti-intellectualism and increased authoritarianism, but also the way we understand and foster democratic values and civic participation." ${ }^{* 4}$ Our scientific approach

${ }^{1}$ The post-truth is defined as 'relating to or denoting circumstances in which objective facts are less influential in shaping public opinion than appeals to emotion and personal belief'. English Oxford Living Dictionaries - <https:// en.oxforddictionaries.com/word-of-the-year/word-of-the-year-2016> 15.06.2017

${ }^{2}$ Oxford definition of post-truth $<$ https://en.oxforddictionaries.com/definition/ post-truth> 12.10.2017

${ }^{3}$ Glăveanu <https://ejop.psychopen.eu/article/view/1509/html >12.10.2017 ${ }^{4}$ Ibid. aims at strengthening the foundations of an open and tolerant society, based on the ideal of social justice underlying the protection of human rights. As Glăveanu V notes, "embracing diversity is essential for the development of societies that are resilient to nationalism, populism, and discriminatory practices". ${ }^{5}$

Nowadays the primary news source for young people is social media filtered by one's own preferences, leading the user into 'reflective channels of similarity'. This deceptive sense of social cohesion and the search for soul-mates is fed by the existing prejudices and the hunger for up-to-date news, no matter whether true or false. Often shared group opinions, subtle emotional influences and, what is more, stories with no relationship to truth make the members of these artificially constructed communities feel accepted and understood. The information age allows 'truth-telling' ${ }^{6}$ to spread almost with the speed of light. As P. Pomerantsev states, "there is some sort of teenage joy in throwing off the weight of facts - those heavy symbols of education and authority, reminders of our place and limitations... By the time a fact-checker has caught a lie, thousands more have been created, and the sheer volume of 'disinformation cascades' make unreality unstoppable."

The US portal fakenewswatch.com groups the fake news into three categories:

1. Fake/Hoax-News - fictitious news written intentionally for the delusion of readers.

2. Satirical sites that generally do the same, but are meant to laugh (not to lie) and often contain some kind of political messages.

3. Clickbait - these sites publish all sorts of messages without concern whether they are true or not. The goal is to quickly attract the attention of the users, often with distorted interpretations of real news.

Fake news is just a part of the media-propaganda. The new media${ }^{5}$ Ibid.

${ }^{6} \mathrm{New}$ ways of communicating post-truth involve overt manipulations or even outright lies disguised as 'true facts'.

${ }^{7}$ P. Pomerantsev - Why We're Post-Fact $<$ https://granta.com/why-were-postfact/> 10.06.2017 
streaming turns the objective reality into a world so complex and fragmented, that it becomes ungraspable and oppressive, making the recipient unable to assimilate it promptly. Fragmentation, combined with disorientation leaves people yearning for a refuge: secure shelter, often built by protective fantasies and fake realities (i.e. 'hyperreality'). In the beginning of the year 2017, the majority of Bulgarians have relinquished critical thinking in favor of emotional commitment, so we are living in a 'post-fact' or post-truth world. A significant number of people believe in the fabrication that at any moment Bulgaria will be flooded by refugees and only Russia can save it. This myth is a framework, a precondition for verification: one may wonder if this is true or not, but only within such a twisted 'picture' put in front of his (her) eyes by the fake news writers. On the other hand, all thoughtful and at the same time open-minded users of (online) media realize that there is a targeted and systematic distortion of the presentation of information in the Bulgarian public sphere. This is a situation in which a certain type of political subject appeals not to his electorate's common sense but to the fears, passions, traumas and envy of the voters. And when all these negative emotions become the primary means of persuasion, then we are talking about a particular propaganda, in which there is no difference between the elementary fact and the brutal lie. Our recently elected new-old politicians ${ }^{8}$ and dependent media don't actually care whether they tell the truth or not. In April 2017, the Humanities and Social Studies (HSS) Foundation published a study called "Antidemocratic Propaganda in Bulgaria". For the purposes of the survey, its authors call 'propaganda' the messages based on the conspiracy logic that there is a global villain (NATO, Open Society and America for Bulgaria Foundations) who runs marionettes (the Brussels officials, obedient politicians, civic organizations) and that citizens are powerless against what is happening. ${ }^{9}$ An integrated research approach was carried out in the following activities - testing some media content in order to:

1. Isolate the main semantic nuclei of the post-true messages.

2. Build a matrix and keys for quantitative analysis of the media environment.

\section{Make a typology on the basis of full standardized press-clipping.}

The analysis covers the content of 3080 online media and blogs published in the period 2013-2016, as well as 3305 articles in eight popular media that systematically give propaganda messages. ${ }^{10}$ The study confirms the impression based on everyday experience that the number of fake news and fabricated sources is increasing and

\footnotetext{
${ }^{8}$ Since 2009 B. Borisov has been a prime-minister of Bulgaria for eight years with short interruptions.

${ }^{9}$ These are consistent system claims, most often with negative suggestions that are not supported by arguments, and therefore different from criticism, the authors said. The Antidemocratic Propaganda in Bulgaria $<$ http:// www.dnevnik.bg/bulgaria/2017/04/11/2951775 antidemokratichnata propaganda_v_bulgariia_evropa/>3.07. 2017

${ }^{10}$ They have different profile, but primarily publish propaganda messages - the "Poghled" ("Look") and "Glasove" ("Voices") sites, the newspaper "Russia Today", the magazine "A-Specto" website, the "Trud" ("Labour") and "Weekend" newspapers, "Duma" (the official media of BSP) and PIK agency. The characteristic feature of these media is that most of their texts are not signed with the author's name, i.e. anonymous articles are 1.5 times more than the copyright materials. Author's position and criticisms are presented mainly when writing on domestic issues, not on international ones. Most of the anonymous material (45\%) is on the topic "the rise of Russia" (in the genre of anonymous reportage), juxtaposed with the "decay of the West". (Ibid.)
}

empirically proves the existence of such propaganda, describing the mechanisms of its functioning. In the recent years this phenomenon is enormous in scale and has been growing steadily. The variations in its frequency are in direct dependence on certain external and domestic political events. ${ }^{11}$ The analysis also takes into account the psychological preconditions that favor the development of propaganda rhetoric. Anti-democratic speech can be seen in the thesis of the 'naïve in its tolerance democratic state' demonstrated in the following ways:

a. Anti-Romani discourse - building long-lasting, dehumanized images of the Roma-people often represented as criminals and benefiting from special privileges.

b. Resurgent anti-Semitic rhetoric - disseminating conspiracy theories about the "Judaism-Masonic plot" driving the social and economic development and crises worldwide.

c. Homophobic attitudes stigmatizing different sexual identities as deviant and opposing the myth of the "Orthodox family values" whose guardian is Russia.

d. Sexism, especially against female politicians ridiculed as "Aunt Tsetska" (alluding to the National Assembly Chairman Tsestka Tsacheva), "Mother Merkel" etc.

e. Non-reflective alignment of Islam with Islamism, equating 'refugees' to 'terrorists'.

In the HSS foundation's analysis the topics of the antidemocratic propaganda in Bulgaria are reduced to four major ones. The first is "the decay of Europe". According to this thesis, the European Union is 'infected' with the virus of liberalism. It is an artificial construct invented by the United States, doomed to fall apart when nations regain their sovereignty. The second thesis is "the raising of Russia". It rises again as a world political, military, and moral leader, as a civilization alternative to the 'rotten West.' "The US and NATO - a global hegemon and puppeteer", this is the third thesis of the propaganda. According to it, behind the ideological front of 'human rights', the United States and the dominated by them military alliance contaminates nations with liberal ideas to deprive them of sovereignty, incites Islamist attacks and migrants against Europe and Russia. The "corrupt Bulgarian elites" is the fourth propaganda pivot, which states that all pro-liberal and pro-European civil and non-governmental organizations advocating for judicial reform and the rule of law are paid by George Soros, the America for Bulgaria Foundation, or directly by Washington authorities. During the four years span of the study:

i. Anti-democratic propaganda materials in some Bulgarian media have increased more than 30 times;

ii. Eurosceptic propaganda has become 16 times more common.

iii. anti-American and anti-NATO propaganda has grown 34 times.

iv. the discrediting of the political elite, civic organizations and prodemocracy movements is 23 times more frequent. ${ }^{12}$

\footnotetext{
${ }^{11}$ Among the important findings of the Humanities and Social Studies Foundation study is that the peaks and the intensity of propaganda messages circulating through the media follow the "Russian political calendar." The start of the 'attack' was given by the Ukrainian EuroMaidan and the Crimean annexation in 2013 - 2014. Before that, there seemed to be no problems with the European Union, neither a danger to the sovereignty of its peoples. (Ibid.) ${ }^{12}$ Ibid.
} 
This, according to the political psychologists, shows that the Bulgarian anti-democratic propaganda is directed inwards and is used to deal with domestic political and economic opponents. And often it is not about Russian propaganda in Bulgaria, but rather about pro-Russian Bulgarian propaganda. The main manipulation line goes through the suggestions that the reception of refugees (e.g. "it is not about taking refugees but about conquering Europe") is a sign of "the sunset of Europe". The opposition between corruptible Europe, which is "defenseless in its misunderstood hospitality" and powerful Russia, which respectively "keeps its borders so well that refugees do not go there", can be seen clearly. Antidemocratic propaganda is also aimed at re-branding the blame for the communist past, as well as downplaying the personal responsibility of eminent social actors. Through this type of propaganda talk, the past is wiped clean and the public images of guilty parties are rehabilitated (an emblematic example of this is the awarding of the Chief of the Sixth Department of the Communist State Security Services, Dimitar Ivanov, with the Order of the Golden Age in 2016). The content analysis was has been accomplished on three major topics with relevant keywords: 1) The image of Europe and the West ("The Sunset of the West"); 2) Russia (represented as a rising country); 3) Lost Bulgaria (focusing on the rotten elites and civil society). This allowed us to identify the presence of certain schemes of interpretation, as well as to determine the role of antidemocratic messages in the justification of post-truth manipulations in Bulgaria. Specific anti-liberal positions were described by: formal and content analysis of the main theses and arguments; - structural analysis - identification of key negatively represented and positively represented actors - personalities, political figures, institutions; - semantic analysis of the ways they are described through epithets, actions, characteristics, etc. More and more furious anti-liberal ideologists are rising up, pushing the public space to the extreme with apocalyptic statements and phobic pictures of what is ahead of us.

In their Bulgarian version, the funniest is that the defects of the liberal and capitalist West are proposed to be treated by the semi-feudal autocratic Russia. And here, as Dostoevsky has said, "everything is allowed" - in Bulgaria, post-truth has become a potential substitute for any inconvenient truth. It is the fig leaf that conceals the shameful reality built by lies, propaganda, defamation and total obedience of the consumers of post-truth in the distorted social environment. Propaganda, which is often used to imply how bad democracy is, aims to legalize and create comfort for individuals directly responsible for this state of affairs. All political subjects with real and tangible presence in the public sphere have their 'media packages'. Or they directly possess media through their stooges, mobsters and oligarchs. This is a total informational war that spares no expense against the opponent. It starts with pseudo-moral recommendations, passes through geopolitical absurdities that prescribe Russia as the true antidote against the 'rotten West' and ends with such blasphemies as "Russians are closer to the transcendent", which is pure nonsense. It is considered acceptable Russian image to be idealized and defended with all sorts of arguments and even brutal lies, hybrid warfare and internet trolls. Today's political left behaves as if it does not remember its historical catastrophes: neglecting the legacy of totalitarianism it extols the state socialism. Unexpectedly, a primitive nationalism is reborn - it is in fact populist xenophobia. These newly hatched nationalists ${ }^{13}$ do not seem to remember the $20^{\text {th }}$ century catastrophes

${ }^{13}$ There is no doubt that one feels homesickness and affection for the place he/she lives in, enjoys pride for its history and cares for its future. But this caused by major European clashes and world wars: the unforgivable Nazi madness that killed millions of people. ${ }^{14}$ How did we get here?

The social uncertainty, the lack of economic prospects, the undermined trust in politicians, academics, traditional media etc. has made the government take over the old institutions of authority. ${ }^{15}$ If all the facts say you have no future, then why would you want to hear facts? For instance, when asked to explain the principles which allow for conspiracy theories to be presented as equally valid to evidencebased research, the heads of Putin's propaganda networks claim that there is no such thing as 'objective reporting'. "The Kremlin's international channel, RT, claims to be giving an 'alternative' point of view, but in practice this means making the editor of a fringe right-wing magazine as credible a talking head as a University academic, making a lie as worthy of broadcast as a fact."16 The equating of truth and falsehood is a consequence of the postmodern relativism ('there are no facts, only interpretations' $)^{17}$ that has permeated everywhere over the past years -from academia to the media. An audience which was already accustomed to a life without facts (guided only by emotions and without any sense), can now indulge in a carefree liberation from objectivity. The following discursive lines of Bulgarian 'post-truth' psychology are particularly important for tracking:

1. To be a functionary of the State Security is not morally reprehensible, because these people were not snitches, but scouts who worked in the name of homeland security.

2. Being a member of the Socialist Party (BSP) - direct successor of the Bulgarian Communist Party cannot be qualified as unacceptable - most of the people have been members of this Party (during the previous regime, it was the only one effective political actor) and some of them are still loyal to its descendant. ${ }^{18}$

3. Communism was not so bad because everyone had a job (education, medical care, housing, etc.). "Now we can speak freely, and what is the benefit of this?"

4. There were only criminals in the Communist death camps during socialism, not political prisoners.

This type of speech, on the one hand, mitigates the individual guilt for life choices and, on the other, blurs the essential differences

attachment is not excuse for total anti-tolerance, xenophobia and racism. Liberalism, on the contrary, is thoughtful - it does not allow irrational passions and dark visions to master consciousness. Rational processes should prevail in politics - it is not poetry. Let us leave the sphere of the strong feelings to individuals and their own fantasy.

${ }^{14}$ The universe of crimes committed by the Nazis is too vast to succumb to generalizations and definite standards of 'right and wrong'. Holocaust is a world in itself - its giant scale crushes Europe. In the collision between Nazi Germany and the Soviet Union, Eastern Europe becomes something that the historian Timothy Snyder calls "bloody field" - a utopia of mass murder.

${ }^{15}$ On May 4, 2017, the 44-th National Assembly, with 133 votes in favor and 100 against, chose for the third time Boyko Borisov as prime minister in the government under the mandate of the Political Party GERB. Borisov is supported by MPs of GERB, the so called "United Patriots" and Volya Party (led by the scandalous businessman V. Mareshky). The latter two are declared nationalist parties and their unreflective nostalgia for the past and for ethnic and cultural homogeneity are ticking time bombs.

${ }^{16}$ Ibid.

${ }^{176}$ Anything goes' means that every version of events is just another narrative, where fake news can be regarded as 'an alternative point of view' or 'an opinion', because everyone has 'their own truth'. 
between a liberal democracy and a socialist dictatorship. It devalues democracy and reduces it to "unemployment", "crime" and "consumption society", thus creating an idealized image of the recent past and the "socialist present" embodied by Russia. According to the findings of the team that worked on the abovementioned analysis, the global risks of anti-democratic propaganda are several:

a. Growing prerequisites for total public cynicism: "All rulers are plunderers!"

b. Suspending the rule of law and replacing it with the rule of force.

c. Deinstitutionalization of democratic mechanisms for separation and mutual control of authorities.

d. Dampening and discrediting the civil society, which ultimately leads to creeping authoritarianism of a populist type?

The results of the study clearly show that there is a systematic and purposeful propaganda that reproduces the same cliches and theses. This propaganda is generally Eurosceptic, anti-institutional - undermining democratic institutions - and also anti-civic, because it suspends the possibilities and desire for civil control. It is quite massive - the number of propaganda media grows, as summarizes the head of scientific team Dimitar Vatsov. ${ }^{18}$ Anti-democratic propaganda systematically devalues the EU institutions in the Bulgarian media environment, discredits the alliance both as a political and as a civilization project. The analysis demonstrates that the manipulated facts create a negative and endangering social framework without prospects for the future, neglecting or rejecting liberal democracy. The systematic rhetorical erosion of liberal democracy's economic psychology could also be interesting to follow. By means of contextbased comparisons between the price of the bread/public transport ticket/holiday card, etc. "before" and "now", the post-truth campaign in Bulgaria is questioning the legitimacy of the regulatory base of market economy. Economic investments are measured with a different yardstick - Western investors are presented as "exploiters, exporting their profits from Bulgaria to the plunderers" in contrast to the attitude towards Russian companies, who actually serve the Bulgarian interests even less. Perhaps one of the reasons for these falsehoods is the lack of a precise distinction between the notions of 'discourse' and 'propaganda', as well as between left (anti-elitist) and anti-democratic (anti-minority) speech. The pro-Russian rhetoric is not necessarily an anti-liberal one. Also, there is nothing wrong with populism, but when it leads to not paying attention to the main problems of society and making the psychological climate worse, instead of improving it, populist discourse has to be prevented. In some respects Bulgaria (located at the crossroads between East and West) may hesitate to decide whether it is a part of the Western world or not - this is a topic for every tavern talk on politics. But if we are talking about fear, we have reason to feel almost unanimous: fear ceases to be just emotion and becomes an attitude, a worldview and way of life. It also becomes a group marker - people like and hate each other depending on what they are afraid of - but in the case of groups, the damage to critical thinking is greater. Let's say some are afraid of refugees and migrants. In Shiroka Luka people lost their minds over two Afghan youths, and in Elin Pelin they were panicked over a Syrian family. The most recent example is from Belene. ${ }^{19}$ Irresponsible quasi-media

${ }^{18}$ Ibid.

${ }^{19}$ Father Paolo Cortezi from the Catholic Church in Belene became a victim of threats and accusations (and later had to leave the country) for a humane act and machines for fake news try to imply that we are facing invasion. But in order to believe them, one must have frightened himself in advance! Educated people who are upset by xenophobia are also afraid. Instead of competing ideas, theses and political programs, the ruling parties rely on nationalist and anti-European rhetoric. The result of their unrealistic promises is the incitement of irrational fears.

Radical media are not the only distributor of fear; the impact of social networks is probably even stronger. Every horror, every outrage, immediately spread via Facebook and Twitter feeds us with a new portion of stress. Ten years ago people exchanged mainly jokes and funny tests in social networks. But gradually they have become a platform for a culture of indignation. We have shrunk our profiles in a balloon of limited acquaintances and possible opinions and we will still come across some misleading, unacceptable, or just monstrous statements. The frightened person does not think much - a drowning man will clutch at a straw. Such guy is not fastidious - if you scare him enough and then offer him help, he will forget, at least temporarily, how you lied to him the previous time. Here is also the emotional aspect turning fear into a spectacle: a show with flags, uniforms, caps, national traitors and so on. It is no coincidence that there are often party benefits where fear dominates.

It seems as if Bulgarian society has become too naive and foolish to believe that when there is pluralism in society, free media and democracy, the truth itself is safeguarded. As if it somehow 'emerges from itself' and overcomes the lie, being stronger, more attractive and ultimately more profitable than deception. But we must remember the example of totalitarianism that has collapsed from the burden of its lies. In the post-communist reality in Bulgaria the truth became almost inconspicuous between millions of fallacies, multiplied in digital and analogue ways. The association "Clean Internet" aims to reveal some sources of fake news in Bulgaria. Its research team has found that by the end of 2015 the fraudulent posts were on extreme anti-Roma and xenophobic themes. At the beginning of 2016 the fake news generators started imposing new topics - "civil war", "terror in Europe", "corruption", and "world conspiracies. In 2017 the focus shifted to advertising posts for the BSP and the pro-Kremlin propaganda praising Putin and Russia.

The content of the eight abovementioned media that has been analyzed by the research team clearly shows focus on four propaganda themes concerning the US, EU, the Eurasian Union and the corrupted elites. The negative characters in these media are twice more than the positive ones and not a single institution has been cited as a good example. "What propaganda does is to shape a nihilistic picture, to normalize the irresolution and inaction, to turn them into moral principles and virtues. Not to give examples of good life, but to exploit some social feelings," explained the team of authors. ${ }^{20}$

- the priest offered shelter to a refugee family from Syria. The refugees were legally residing in the country - they had all the documents for legal status and were directed to Belene by the State Agency for Refugees. According to Father Paolo, it was intelligent family - people spoke several languages and wanted to work there observing the laws of Bulgaria. Against the refugees stood up the municipal councilor from the local Patriotic coalition Krasimir Todorov, nationalists and 'dissatisfied people'. Todorov explained that some citizens worried about the possibility refugees to be permanently accommodated in Belene - once welcomed, they might be followed by many others.

${ }^{20}$ The Antidemocratic Propaganda in Bulgaria <http://www.dnevnik. bg/bulgaria/2017/04/11/2951775_antidemokratichnata_propaganda_v_ bulgariia evropa/>3.07. 2017 
Those who distribute fake news usually want to attract people's attention. But sometimes they purposefully try to do harm. Because such nonsense is shared in social networks hundreds of thousands of times, many think 'There should be something true in this story'. Such an attitude is often used by radical nationalists who deliberately put out fake news to embarrass and confuse people and tune them in favor of their paradoxically pro-Russian 'ideas'. Among the supporters of extreme right, semi-fascist ideas is spreading an increasingly aggressive mistrust of traditional media, accused of lies and manipulations. 'Alternative' news sites are actively helping to discredit traditional media by fueling emotions and are not really interested in facts. In an increasingly complex world, they profess the creed that people do not need truth but excitement and most of all the sufferers insist on reassurance. As the German expert Sasha Lobo notes, most authors of fake news and some of the consumers have long forgotten moderation at the expense of agitation. The distracted, irritated, tired of thinking citizens are supposed to be easily administered and controlled. ${ }^{21}$

Is truth a matter of point of view? When the information space is flooded with nonsense, the fatigued users become susceptible to manipulation. In the age of post-truth, the journalistic profession gradually disappears, claims Prof. Ivaylo Dichev in his essay "The Myth of Conspiracy and the Ritual of Transparency". Threatened by poverty many of the information front-line employees are being forced to work for the propaganda machine. They are no longer the 20th-century ideologists who ardently stand up for one position or another. They are invisible anonymous workers whose efforts do not make sense individually, but only in their entirety - as with the advertising campaigns. A Bulgarian IT specialist working in Canada soon demonstrated that more than half of the news sites in Bulgaria are anonymous - he developed a filter that detected unverified sources. We can imagine how in the near future such programs will send warning messages when we click on a given site: "Attention, the same author(s) claimed the opposite a year ago."

\section{Conclusion}

The objectives, tools and methods of our exploratory study were formulated, identified and tested in the research process. We present quantitative methods for exploration the data of the study: key figures indicating the problem of post-truth in Bulgaria, the new discourse strategies and types of speech and their media dissemination for the period 2013 - 2017. For this purpose an integrated research approach has been developed, which includes:

\section{Press-clipping.}

2. Measuring the frequency of use of post-truth language.

3. Typological sample of media for content analysis.

Here we summarize the results of our survey conducted at the beginning of 2017. For the purposes of the study we collected and analyzed:

a. The specific language of post-truth and its psychological implications.

b. Some anti-democratic suggestions found in the Bulgarian media environment and their main reference points.

\footnotetext{
${ }^{21}$ Dichev, Iv. - "RIP journalists" <http://www.dw.com/bg/rip-журналисти /a-36893359>12.06.2017
}

c. The rise of propaganda and its exponential growth during the period from 2013 to 2016.

d. The types of media engaged in dissemination of fake news and manipulative messages.

e. Their sources and distribution networks.

The scientific work in the research and analysis follows the results of the project "Anti-liberal Discourses and Propaganda Messages in the Bulgarian Media: Dissemination and Social Perception". Posttruth is an opinion represented as a fact that influences emotions and often ignores common sense (acts through excitement, not through reason). The concept has caused far more comments than usual because it attempts to capture what is happening all over the world, constructing new paradigms based on semi-truths and untruths. Simply put - paradigms based on lies and falsified facts on which a new 'world order' is built. The phenomenon of establishing a whole new, distorted reality in which people decide on the basis of erroneous information is used by media that have an interest in global and local uncertainty. One of the most serious aspects of fake reality is that it offers easy solutions. Of course, these are totally unreal, but people want quick response and 'easy to digest' answers right away. In addition, it also suggests that morality is relative, that some lives are more valuable than others and that in some circumstances violence is warranted.

The main question is what future does Europe want? Societies promoting tolerance, or such in which toleration towards different from the conventional opinion is seen as "pernicious poison"? As for any anti-European rhetoric, the paradox is that the vast majority of Bulgarians are not Euro-skeptics, but on the contrary. But those who are Euro-haters trumpet the falsehood everywhere and have relevant media channels that make them speak so loudly. False reality is an effective recipe for a global catastrophe. The Eastern European heritage - oppression and terror - has succeeded in penetrating people's perception of their future. Where democratization failed, the collapse brings all the evils of crowd psychology and mass politics, without much benefit. In such a reality, people are gropingly looking for a way to understand their world. Ideologies arrive as panacea from distant lands and often come across people who do not know what their purpose exactly is.

We must critically address any type of propaganda because it has many negative institutional effects: it induces skepticism, nihilism; it also discourages the supporters of liberal democracy and of the European Union. It is extremely important to emphasize that propaganda is not criticism. Propaganda suggests certain theses and imposes them in a completely uncritical way, mainly through anonymous materials. There is no dialogue driven by aspiration to change things - the idea is not to show the weaknesses of liberal democracy but to discredit it. Not to criticize the European Union, but to work towards its dissolution and falling apart. This is a verdict, not a trial. And it is not just a question of criticism, or counter-propaganda to the massive and purposeful attack seeking to remove criticism. The misuse of social media and disinformation campaigning is tantamount to waging a cyber war. We have no antidote against hybrid warfare by anonymous-run media. So we are still far from what we ultimately expect to be the late modern information environment.

What we need now is a comprehensive strategy to counter the propaganda efforts and a holistic approach focusing not only on media, but on malicious information technologies at large. The 
implementation of fake news-filters is just a part of the projects aimed to preventing disinformation campaigns and high-tech propaganda operations. We should not look for excuses as the inconsistency of fate, the inevitability of history, and the universal absurdity of life. "It is imperative, now more than ever, that psychologists use their expertise to devise practical tools for cultivating critical thinking and reflexivity in relation to a number of areas of social life - e.g., history, politics, economics - and in relation to the distinction between personal beliefs and objective facts". ${ }^{22}$

The so-called elites - political, economic, media, intellectual, and so on - must urgently stop spreading populism, creating parallel reality etc. because someday this bubble will burst painfully. Instead, we need to look for effective solutions to all the pressing problems social, economic and military crises, which in turn lead to poverty, insecurity, migration, fear and indignation. The manipulation of public opinion relies on sudden twists, unfulfilled ambitions and unpleasant surprises. We have to repeat the truth constantly and speak openly about any type of potential threats. The problem is that the truth does not look attractive enough, profitable or as easily achievable as posttruth. But the result of grasping it is living in dystopia. What is at stake is our future - that is why it is crucial to maintain confidence in the

${ }^{22}$ Glăveanu

$<$ https://ejop.psychopen.eu/article/view/1509/html>12.10.2017 political framework of our society, in the democratic values and EU membership. $^{1-5}$

\section{Acknowledgement}

None.

\section{Conflict of interest}

None.

\section{References}

1. Kiosev. The major catastrophes of the twentieth century are repeated. 2017.

2. Znepolsky. It is very important propaganda not to be confused with criticism. 2017.

3. Exposure of Conspiracy. Excerpt from the new book by Ivaylo Ditchev. Logbg. 2017.

4. Father Cortezi, who sheltered Syrians in Belene, leaves Bulgaria. Off News. 2017.

5. Parkinson J, Kantchev G. Document: Russia Uses Rigged Polls, Fake News to Sway Foreign Election. The Wall Street Journal. 2017.

6. Spassov S. Putin's war on the "second Europe". Online Trading. 2017. 